\title{
Modern innovation challenges to firms and cities: the case of Portugal
}

\author{
Silvia Fernandes ${ }^{1 *}$, Marisa Cesário ${ }^{1}$, Guilherme Castela ${ }^{1}$
}

\begin{abstract}
Modern competition is tough due to emergent information systems and technologies. Managers must cope with these challenges continuously to keep their businesses sustainable. An important step is to employ strategies based on open innovation. This work analyses where Portugal stands in terms of innovation in general, propensity for open innovation and innovation sustainability. An HJ-Biplot methodology was applied to a valid sample from CIS 2012 (Community Innovation Survey). It suggests that Portuguese firms must cut back on activities that are not leading to the outcomes needed. Also, with the right partners they can have more ideas executed and diffused.
\end{abstract}

Keywords: innovation accelerators; open innovation; innovation return; customer-driven; competitor-driven; HJ-Biplot.

Submitted: March $7^{\text {th }}, 2018$ / Approved: July $10^{\text {th }}, 2018$

Modern innovation challenges to firms and cities: The case of Portugal

We are witnessing the need for a quick and intelligent reaction from organizations regarding the level and speed of change in business models. This is often associated with the emergence of new information systems and technologies (IS/IT). Aligning the information systems' portfolio management with the business goals is a key challenge. This alignment allows for adjusting enterprise process architecture to the prospects of the business. This can be a flexible approach to manage the potential adherence to new systems such as mobile, cloud, bigdata or Internet of Things (IoT) which tend to proliferate.

The transition from the industrial society to the information society gave rise to new issues such as information and knowledge management. The increasing ability to manage large volumes of data in big databases, using advanced tools for analysing those data, can respond to more selective and diverse requirements. Some of these involve rethinking the ways to present products/services and seeking different dissemination channels.

Connectivity, mobility, pervasiveness and real-time accomplishment are some of the keywords used in the context of business competitiveness. The sustainability of competitive advantage is found in the company's ability to generate the business intelligence that enables it to constantly rethink its goals and models to suit its market needs in real time. Given the actual pace of change and instability, companies must deal well with opportunities. This requires that organisations and their personnel adopt new ways of managing business responses to numerous emerging challenges.

For example, the overwhelming potential of the internet has led to new process architectures in companies. A network of smart devices can be used to enhance working methods and create new services. Mobile work empowerment is possible, which is important for realtime responses. Captured on a continual mobile basis, dynamic information and resources can bring positive transformative changes (Hassanalieragh et al., 2015; Tyagi et al., 2016; Niewolny, 2013). All these challenges and potentials have been considered and explored by the so-called innovation accelerators or 'boot camps', either for launching new businesses (mainly start-up generation) or supporting their IS/IT platforms.

\section{Innovation accelerators: Concept and potential}

An innovation accelerator is an intensive business programme (usually three months) which includes mentorship, educational components, and networking, and aims to help businesses grow rapidly. It is an open, entrepreneurial and interdisciplinary environment. Usually the entrepreneur moves into a shared space with other new founders to work under the tutelage of advisors and experts. In exchange for expert mentoring, exposure to investors and a cash investment from the accelerator, the entrepreneur gives a portion of their company's equity to the partners of the programme, and for this reason it is often called a 'seed' or 'venture' accelerator. Other elements include:

- The accelerator programme, which consists of five elements (Christiansen, 2009): 1) funding, typically at the seed level; 2) company founders, small teams with technical backgrounds; 3 ) each group is supported for a defined period of time; 4) an education programme, focusing on business advice and/or product advice; and 5) a networking programme, to meet other investors and advisors. Accelerator programmes may include office space (whether free or subsidised) and a demonstration day for funded companies;

- An accelerator programme model, which comprises five main features that set it apart from other approaches to investment or business incubation (Miller and Bound, 2011): 1) an application process, open to all yet highly competitive; 2) provision of pre-seed investment, usually in exchange for equity; 3) a focus on small teams, not individual founders; 4) time-limited support, comprising programmed events and intensive mentoring; and 5) groups or 'classes' of start-ups rather than individual companies;

- Seed accelerators, which are fixed-term, cohort-based programmes that include mentorship and educational components and culminate in a public pitch event or demonstration day. While traditional

(1) Faculty of Economics \& CIEO, University of Algarve, Portugal

Corresponding author: sfernan@ualg.pt 
business incubators are often government-funded and focus on biotech, medical technology, clean tech or product-centric companies, accelerators can be either privately or publicly funded and focus on a wide range of industries.

\section{Innovation accelerators in Portugal}

The innovation scene in Portugal

Recent innovation metrics for countries can be found in an important secondary dataset, the CIS-2012 (DGEEC, 2014). The Community Innovation Survey (CIS) is the main statistical survey (mandatory for EU member states) on innovation in companies. The European Union employs this statistical instrument to monitor Europe's progress in the area of innovation, as conducted by national statistical offices. In Portugal, following the recommendations of Eurostat, the CIS aims to directly collect information on innovation (product, process, marketing, and organisational) in companies. Data collection, corresponding to the period of 2010-2012, was performed in 2014 through an online electronic platform. It considered Portuguese companies with ten or more employees belonging to several NACE codes (economic activities). Among the 7995 companies in the corrected sample, 6840 valid answers were considered corresponding to a response rate of $86 \%$.

The CIS instrument also provides useful information about how firms are interrelated with their surrounding external environment in order to access information considered important for the development of new innovation projects or the completion of existing ones. Firms may use external agents as information sources or engage in more formal cooperation activities, meaning their active participation with other enterprises or institutions on innovation accomplishments. But which sectors innovate the most? Is it cooperative or firm-based innovation? The following figures will help to analyse factors that explain the level and nature of innovation in Portugal (DGEEC, 2014).

In terms of products/services, the most innovative sectors are computer and information, followed by health, machinery and finance (Figure 1).

Figure 1. Product innovation indicators.

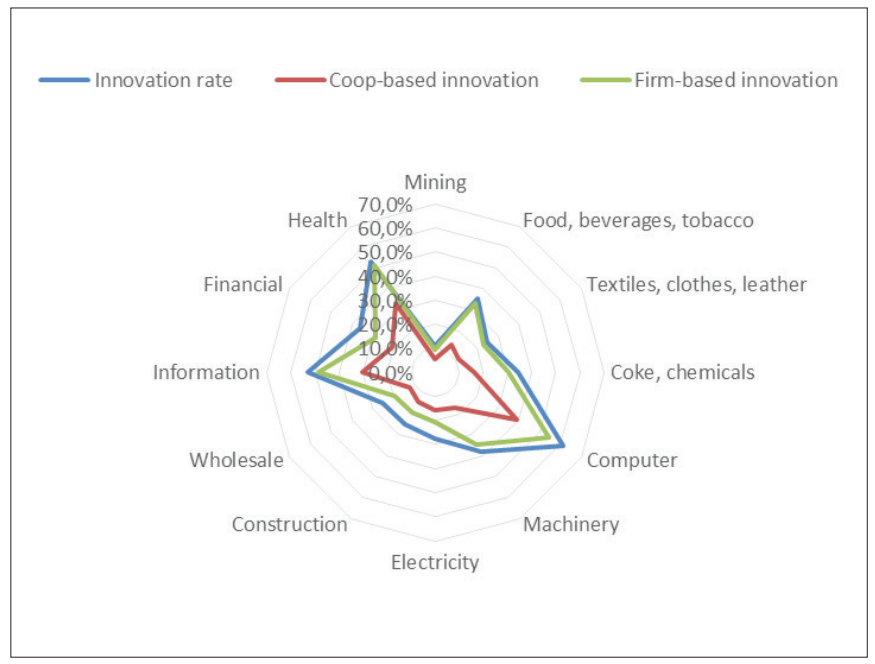

In terms of process innovation, the most innovative sectors are computers and health, followed by construction, electricity and information (Figure 2).

Figure 2. Process innovation indicators.

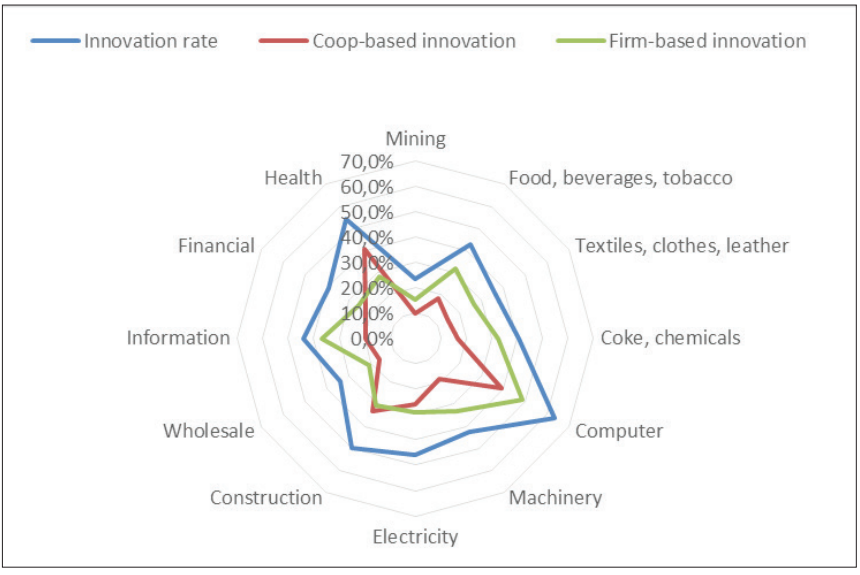

\section{Innovation challenges}

External knowledge connections are a vital factor in the open innovation model (Cohen and Levinthal, 1990; Veugelers, 1997; Chesbrough et al., 2006). Firms that are internally centred need to open their boundaries to external partners, otherwise numerous opportunities are missed (Chesbrough, 2003a; Laursen and Salter, 2006). Several studies support the idea that a firm's boundary requires porosity to absorb knowledge and abilities from the environment (Shan et al., 1994; Leonard-Barton, 1995; Powell et al., 1996; Chesbrough, 2003b). This can provide an extensive variety of novel ideas and innovation opportunities (Laursen and Salter, 2006; Powell et al., 1996) and access to complementary resources that turn an innovation into a market success (Cohen and Levinthal, 1990).

Figure 3 compares Portugal to other European countries, illustrating that Portugal has a low level of cooperation-based innovation (based on Eurostat data). In 2012, the countries with the highest levels were the United Kingdom and Belgium, followed by Austria and Denmark. The indicator decreased from 2008 to 2012 for most countries, including those with the highest values.

Figure 3. Percentage of cooperation-based innovation firms ${ }^{1}$.

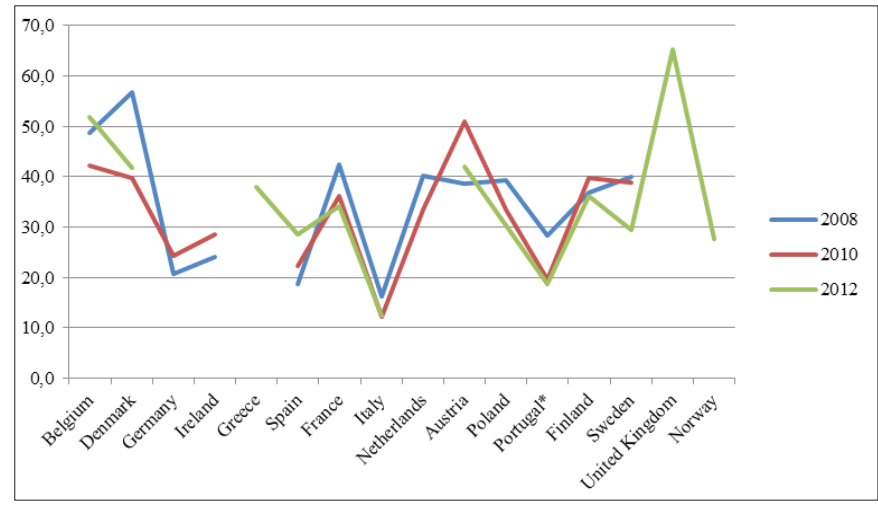

(1) The line cuts in this chart correspond to data not available for the respective countries/years. 
In terms of exports of high tech products, this percentage has increased in general. However, Portugal and Greece still have the lowest levels (Figure 4).

Figure 4. Percentage of exports of high tech products.

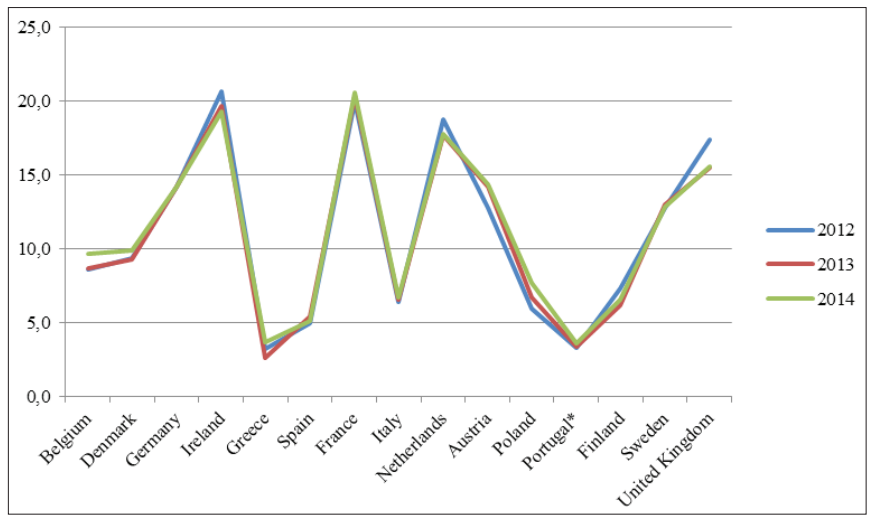

Another relevant indicator to consider is venture capital investment, and Portugal also has a low level (Figure 5).

Figure 5. Venture capital investment.

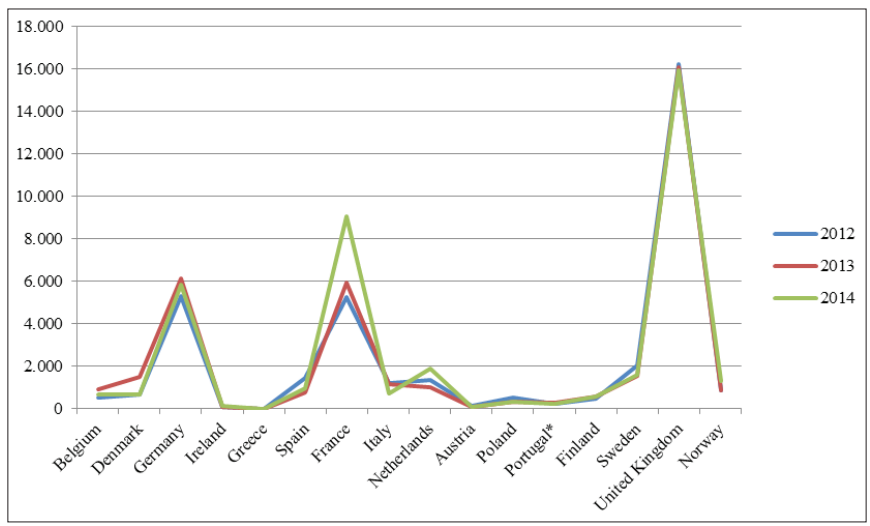

These three indicators (cooperation-based innovation, exports of innovative products and venture capital investment), which can be related to open-innovation propensity, suggest that Portugal still has a long way to go. Global Entrepreneurship Monitor (GEM) suggests that about 8 in 100 people are entrepreneurs in Portugal (involved in start-ups) and that 1 in 2 entrepreneurs do it out of necessity ${ }^{2}$. Reasons include: the low incomes characterising this country, missing early collective entrepreneurial culture (path-dependent), difficulties obtaining finance and risk adverse (Sarkar, 2014). These issues may be related with the 'maturity level' of innovation acceleration in Portugal and the sustainability of the resulting innovation.

\section{Innovation acceleration potential}

A question emerging from the previous assessment is how the openinnovation challenge should be addressed and overcome. Innovation accelerator environments can be real open innovation engines, due to their entrepreneurial and interdisciplinary ambience.
One of the best start-up accelerators in the world is Techstars in Boston, USA (http://www.techstars.com/). Fewer than 1\% of the companies that apply to it are accepted. One of the few Portuguese start-ups accepted was DoDOC. This company, established in February 2014 by three students in the MIT doctoral programme, was chosen from among 1500 candidates around the world. DoDOC is focused on enterprise solutions for document management, enabling the automation of steps where text outputs require the management of several documents obeying strict rules. The company focuses on pharmaceutic and biotech firms, hospitals and universities as these organisations generate high volumes of documents and require a secure and organised way of accessing information. It developed a platform that optimises such processes. DoDOC was one of the 10 finalists of the Lisbon Challenge and is a great example of the growth of the Portuguese entrepreneurship ecosystem in recent years. Some successful innovation accelerators in Portugal are 'Startup Lisboa' and 'Beta-i'. Other recent Portuguese innovation accelerators are 'ASA' (Anje Startup Accelerator); 'Fábrica de Startups'; 'Startup Pirates'; and 'CRIA'.

The statistics about the activity of these accelerators raise another issue concerning the sustainability of the accelerated firms over time. Table 1 shows the case of Beta-i in terms of the number of accelerated start-ups (period from 2013 to 2015) and the percentage of those still active (data provided by a start-up manager at Beta-i).

Table 1 Beta-i acceleration results by sector/market

\begin{tabular}{|c|c|}
\hline Sector/market & No \\
\hline Agriculture \& Farms & 2 \\
\hline Analytics & 3 \\
\hline Biotechnology & 3 \\
\hline Business \& Productivity & 23 \\
\hline Construction & 1 \\
\hline Creative Industries & 5 \\
\hline Education & 13 \\
\hline Electronics & 5 \\
\hline Energy \& Clean Tech & 4 \\
\hline Entertainment \& Leisure & 14 \\
\hline Fashion & 1 \\
\hline Finance & 11 \\
\hline Food, Beverages \& Tobacco & 4 \\
\hline Health \& Healthcare & 9 \\
\hline Marketing \& Advertising & 16 \\
\hline Pets & 2 \\
\hline Real Estate & 3 \\
\hline Retail \& Distribution & 9 \\
\hline Sports & 7 \\
\hline Telecommunication & 4 \\
\hline Tourism & 19 \\
\hline Transportation & 2 \\
\hline Total & 160 \\
\hline
\end{tabular}

Percentage of start-ups still active: $68 \%$

(2) There are several types of entrepreneurship: necessity, opportunity, social, family-type, etc. 
In Beta-i, the sectors/markets with more accelerated start-ups (in descending order) are: business and productivity; tourism; marketing and advertising; entertainment and leisure; education; and finance. Another case that provided data is CRIA (CentRe for Innovation in Algarve ${ }^{3}$, data provided by its coordinator Hugo Barros). Table 2 shows the number of accelerated start-ups and the percentage of those still active (period from 2011 to 2013). Here, agro-food, tourism, information technology and environment/energy are the sectors/ markets with more accelerated firms. These results (in Tables 1 and 2) may reflect the specialisation and university research in the areas included (Lisbon-Center in Beta-i and Algarve in CRIA) despite the increasing number of international firms. Other accelerators were contacted, such as 'Fábrica de startups', but did not provide any data.

Table 2 CRIA acceleration results by sector/market

\begin{tabular}{l|c}
\hline \multicolumn{1}{c|}{ Sector/market } & No \\
\hline Agro-food & 10 \\
\hline Tourism & 8 \\
\hline Information Technology & 6 \\
\hline Design and Communication & 6 \\
\hline Sea sciences & 5 \\
\hline Environment and Energy & 5 \\
\hline Biotechnology & 4 \\
\hline Health & 4 \\
\hline Engineering & 3 \\
\hline Other & 9 \\
\hline Total & 60 \\
\hline
\end{tabular}

Percentage of still active start-ups: 70\%

An issue that emerges from these tables is the sustainability over time of the accelerated firms through their innovations. Both percentages of start-ups that are still active (68\% in Beta-i and 70\% in CRIA) are significant. But how do these figures evolve over time? A recent study by Allmand Law found that more than $90 \%$ of all tech start-ups fail (Dalakian, 2013). What causes failure? One issue is related to confusion about what the added value actually is. Some firms fail to understand the changing needs of their users. It is important to have a feedback structure for users and analyse the information obtained.

\section{The advent of open innovation}

Open innovation initiatives are helping many firms to enhance innovation return and business advantage. Regarding this evolution, Table 3 presents the seven generations of innovation models which express these issues and trends (IPACSO, 2014; Du Preez et al., 2006).
Table 3 Innovation generations

\begin{tabular}{|c|c|c|c|}
\hline $\begin{array}{c}\text { Model/ } \\
\text { generation }\end{array}$ & Characteristics & Strengths & Weaknesses \\
\hline $\begin{array}{l}\text { Technology } \\
\text { Push/1st } \\
\text { generation }\end{array}$ & $\begin{array}{l}\text { Linear sequential } \\
\text { process. Emphasis } \\
\text { on R\&D and } \\
\text { science. }\end{array}$ & $\begin{array}{l}\text { Simple } \\
\text { Radical } \\
\text { innovation }\end{array}$ & $\begin{array}{l}\text { Lack of feedback } \\
\text { No market } \\
\text { attention } \\
\text { No networked } \\
\text { interactions } \\
\text { No technological } \\
\text { instruments }\end{array}$ \\
\hline $\begin{array}{l}\text { Market } \\
\text { Pull/2nd } \\
\text { generation }\end{array}$ & $\begin{array}{l}\text { Linear sequential } \\
\text { process. Emphasis } \\
\text { on marketing: } \\
\text { the market is the } \\
\text { source of new ideas } \\
\text { for R\&D. }\end{array}$ & $\begin{array}{l}\text { Simple } \\
\text { Incremental } \\
\text { innovation }\end{array}$ & $\begin{array}{l}\text { Lack of feedback } \\
\text { No technology } \\
\text { research } \\
\begin{array}{l}\text { No networked } \\
\text { interactions } \\
\text { No technological } \\
\text { instruments }\end{array} \\
\end{array}$ \\
\hline $\begin{array}{l}\text { Coupling/3rd } \\
\text { generation }\end{array}$ & $\begin{array}{l}\text { Interaction between } \\
\text { different elements } \\
\text { and feedback } \\
\text { loops between } \\
\text { them. Emphasis on } \\
\text { integrating R\&D } \\
\text { and marketing. }\end{array}$ & $\begin{array}{l}\text { Simple } \\
\text { Radical and } \\
\text { incremental } \\
\text { innovation } \\
\text { Feedback } \\
\text { between phases }\end{array}$ & $\begin{array}{l}\text { No networked } \\
\text { interactions } \\
\text { No technological } \\
\text { instruments }\end{array}$ \\
\hline $\begin{array}{l}\text { Interactive/4th } \\
\text { generation }\end{array}$ & $\begin{array}{l}\text { Combination of } \\
\text { push and pull } \\
\text { models. Integration } \\
\text { within firm and } \\
\text { emphasis on } \\
\text { external linkages. }\end{array}$ & $\begin{array}{l}\text { Actor } \\
\text { networking } \\
\text { Parallel phases }\end{array}$ & $\begin{array}{l}\text { Complexity, need } \\
\text { of reliability } \\
\text { No technological } \\
\text { instruments }\end{array}$ \\
\hline $\begin{array}{l}\text { Network/5th } \\
\text { generation }\end{array}$ & $\begin{array}{l}\text { Emphasis on } \\
\text { knowledge } \\
\text { accumulation and } \\
\text { external linkages. } \\
\text { Systems integration } \\
\text { and extensive } \\
\text { networking. }\end{array}$ & $\begin{array}{l}\begin{array}{l}\text { Pervasive } \\
\text { innovation }\end{array} \\
\text { Use of } \\
\text { sophisticated } \\
\text { technological } \\
\text { instruments } \\
\begin{array}{l}\text { Networking } \\
\text { to pursue } \\
\text { innovation }\end{array} \\
\end{array}$ & $\begin{array}{l}\text { Complexity, need } \\
\text { of reliability }\end{array}$ \\
\hline $\begin{array}{l}\text { Open } / 6 \text { th } \\
\text { generation }\end{array}$ & $\begin{array}{l}\text { Internal and external } \\
\text { ideas as well as } \\
\text { internal and external } \\
\text { paths to market } \\
\text { can be combined } \\
\text { to advance the } \\
\text { development of new } \\
\text { technologies. }\end{array}$ & $\begin{array}{l}\text { Internal and } \\
\text { external ideas } \\
\text { as well as } \\
\text { internal and } \\
\text { external paths } \\
\text { to market can } \\
\text { be combined }\end{array}$ & $\begin{array}{l}\text { Assumes capacity } \\
\text { and willingness } \\
\text { to collaborate and } \\
\text { network } \\
\text { Risks of external } \\
\text { collaboration }\end{array}$ \\
\hline $\begin{array}{l}\text { Extended } \\
\text { innovation } \\
\text { network/7th } \\
\text { generation }\end{array}$ & $\begin{array}{l}\text { Network models } \\
\text { combined with } \\
\text { open innovation. } \\
\text { Hybrid models are } \\
\text { fundamental given } \\
\text { the construction } \\
\text { of trust and } \\
\text { tacit knowledge, } \\
\text { exchange needs, } \\
\text { physical proximity } \\
\text { and personal } \\
\text { contact. }\end{array}$ & $\begin{array}{l}\text { To fully exploit } \\
\text { all concepts } \\
\text { of open } \\
\text { innovation, } \\
\text { enterprises } \\
\text { should develop } \\
\text { integrated } \\
\text { knowledge } \\
\text { networks } \\
\text { Networked } \\
\text { or webbed } \\
\text { communities } \\
\text { are the open } \\
\text { and agile } \\
\text { vehicles to } \\
\text { deploy open } \\
\text { innovation } \\
\text { concepts }\end{array}$ & $\begin{array}{l}\text { This will however } \\
\text { require new ways } \\
\text { of collaboration } \\
\text { between } \\
\text { enterprises whilst } \\
\text { also competing } \\
\text { concurrently }\end{array}$ \\
\hline
\end{tabular}

(3) http://www.cria.pt/empreendedorismo/spin-offs-e-start-ups/

ISSN: 0718-2724. (http://jotmi.org) 
In contrast to closed innovation, where innovation activities take place entirely within one firm, open innovation processes span across firm boundaries presenting opportunities to reduce risk and commercialise both external ideas and internal ideas externally. More recently, other firms are integrating open innovation tightly with corporate growth and corporate renewal objectives. This leads to a new application of open innovation: when the collaboration with technology partners takes place mainly to build new internal (technological) competences. Once open innovation is tightly linked with corporate (growth) strategy, scholars can use a broad stream of literature about exploration/exploitation and the need to have an ambidextrous company (Jansen et al., 2012). An ambidextrous organisation is capable of simultaneously exploiting existing competencies (e.g., satisfying existing customers) and exploring new opportunities (e.g., developing new products) (Schreuders and Legesse, 2012).

A case study in this regard is Procter \& Gamble (P\&G), whose problem was considerable $R \& D$ spending that impacted performance. This is a classic case of 'Innovation Commitment' increase without a corresponding increase in 'Innovation Competence' (considering the innovation management matrix of Kastelle, 2012). By 1999, R\&D expenditure had increased from around $4 \%$ to nearly $7 \%$ but the new product success rate was stuck at $35 \%$. P\&G had developed a considerable collection of patents, but fewer than $10 \%$ were being used in actual products. At this point, $P \& G$ was "bewildered" as it was sinking a huge amount of resources into innovation, but without a good return on the investment. Then they initiated the 'Connect \& Develop' programme, designed to use open innovation to improve innovation outcomes. They significantly reduced their R\&D spending, cutting back on activities that were not leading to the outcomes they needed. With the right partners, the next step was to get more ideas out into the world. Thus, they moved into the 'Fit for Purpose' phase, getting better at executing ideas and learning about how to use resources more effectively. They improved their idea selection process, and their 'Innovation Competence' took a jump forward.

Those initiatives led them to results like: extensive research networks (both proprietary and open ones) that regularly lead to the development of new ideas; percentage of patents in use in products that increased from less than $10 \%$ to more than $50 \%$; new product success rate that increased from $35 \%$ to more than $50 \%$; and percentage of new products, which include elements developed outside the firm, that increased from $15 \%$ to over $35 \%$. The end result is that $P \& G$ is now considered one of the most innovative companies and a world leader in open innovation. When things are not going well, it does not make sense to increase what is currently done. $P \& G$ realised that it was not effective in the entire idea management process. The 'Connect \& Develop' programme enabled $\mathrm{P} \& \mathrm{G}$ to bring its ideas to market in collaboration with partners better equipped to deal with the relatively smaller returns. This also led to more experimentation, which improved both its selection and diffusion processes.

\section{Innovation return management}

In Portugal, start-ups represent $6.5 \%$ of businesses and $18 \%$ of new jobs (Faria, 2013). On average, 74\% effectively start their activity. Start-ups involve an average of 46,000 people and 2,600 companies per year. Services, retail and accommodation are the sectors with more new companies. There is a decrease in the percentage of companies in the real estate and construction sectors. The survival rate decreases as age advances; thus, the first years are especially important for start-ups. After three years, less than $50 \%$ exhibit activity. By the fifth year, the survival rate is $40 \%$. These figures raise the issue of innovation sustainability and payroll. This can be related with a path dependency of our country in terms of an entrepreneurial culture which is risk adverse and does not have effective idea management. Firms have splendid ideas but lack management maturity to select the best ones or the most returnable ones (which can be developed through partnerships). That is why Kastelle (2012) proposed a matrix of progress in innovation management, where open innovation adoption makes the difference ${ }^{4}$. It is important to analyze and discuss where Portuguese firms stand on this evolution or maturity assessment. To pursue this overall goal, we took related variables from the CIS 2012 dataset.

\section{The CIS instrument}

For this study, a secondary dataset was used from the CIS 2012 (DGEEC, 2014). The CIS (Community Innovation Survey) is the main European statistical survey about innovation in companies. It monitors Europe's progress in the area of innovation, being conducted by national statistical offices. Following EU methodological recommendations, it aims to collect information on innovation in products, processes, marketing and organization. Data collection (in the period of 2010-2012) contemplates Portuguese firms with 10 or more employees. The sample consists of 9423 companies, based on census combination (for companies with 250 or more employees) and random sampling for other companies. From the 7995 companies of the corrected sample 6840 valid answers were considered, what means a response rate of $86 \%$.

According to CIS structure, a firm may be engaged in one or more of the following situations:

a) Product innovation, which occurs when a firm introduces a new or significantly improved good/service to the market. It does not need to be new to the market but must be new to the firm;

b) Process innovation, which occurs when a firm implements a new or significantly improved production process, or method of supplying services or supporting activity. Purely organisational or managerial changes are excluded. Again, it does not need to be new to the market but must be new to the firm (regardless whether

(4) Other authors that explored these aspects are Acquisti et al. (2002), who present a model of innovation generations and their attributes and challenges. 
originally developed by the firm or not);

c) Ongoing or abandoned innovation activities, which include any innovation activities that did not result in a product or process innovation because the activities were either abandoned or suspended before completion or are still going on.

The Portuguese subsample of CIS-2012 used, including 6840 firms, has the sectoral distribution presented in Table 4 . The majority of firms have up to 49 employees and almost half of the sample firms $(48.8 \%)$ affirm having performed product, process or on-going innovation activities. Within this group $26.5 \%$ engaged in cooperation relationships for innovating.

Table 4 Sample characterization

\begin{tabular}{|c|c|c|}
\hline Variables & $\begin{array}{l}\text { No. of } \\
\text { Firms }\end{array}$ & $\%$ \\
\hline \multicolumn{3}{|l|}{ Nace (economic activity) } \\
\hline Mining and quarrying & 73 & 1.1 \\
\hline Food, beverages, tobacco & 323 & 4.7 \\
\hline Textiles, wearing, leather, wood, paper, printing & 889 & 13.0 \\
\hline Coke, chemicals, non-metal, metal products & 1436 & 21.0 \\
\hline Computer, electrical equip & 144 & 2.1 \\
\hline Machinery, transport equip, furniture & 808 & 11.8 \\
\hline Electricity, gas, water supply, sewage, waste & 284 & 4.2 \\
\hline Construction & 36 & .5 \\
\hline Wholesale, retail trade, transportation, storage & 1642 & 24.0 \\
\hline Information, communication & 376 & 5.5 \\
\hline Financial, insurance, legal, accounting, others & 735 & 10.7 \\
\hline Health & 94 & 1.4 \\
\hline Total & 6840 & 100.0 \\
\hline \multicolumn{3}{|l|}{ Number of employees } \\
\hline $10-49$ & 4320 & 74.8 \\
\hline $49-250$ & 1073 & 18.6 \\
\hline$>250$ & 383 & 6.6 \\
\hline Total & 5776 & 100 \\
\hline \multicolumn{3}{|l|}{ Product/Process/On-going innovation activities } \\
\hline No & 3499 & 51.2 \\
\hline Yes & 3341 & 48.8 \\
\hline Total & 6840 & 100 \\
\hline \multicolumn{3}{|l|}{ Cooperation towards innovation activities } \\
\hline No & 2456 & 73.5 \\
\hline Yes & 885 & 26.5 \\
\hline
\end{tabular}

An HJ-Biplot analysis was applied to a sub-sample of 2172 firms from CIS-2012 with valid information for all the variables considered relevant for the analysis of innovation sustainability and propensity for open innovation (see Table 5).

\section{The HJ-Biplot methodology}

A Biplot is a graphical representation of multivariate data. Just as a scatter diagram shows the joint distribution of two variables, a Biplot represents three or more variables. An HJ-Biplot (Galindo,
1986) for a data matrix Xnxp is defined as a multivariate graphical representation using markers $\mathrm{j} 1, \mathrm{j} 2, \ldots, \mathrm{j}$ for the rows and $\mathrm{h} 1, \mathrm{~h} 2, \ldots$, hp for the columns, selected so that both markers can overlap in the same reference system with the highest quality of representation. Rows are represented by dots and columns by vectors. Less stable attributes are represented by longer vectors.

The variables

Table 5 presents the dataset variables in the analysis. Among the variables from CIS 2012, we considered these as most related with the issues of innovation sustainability and propensity for open innovation.

Table 5 Variables in the dataset

\begin{tabular}{|c|c|c|}
\hline \multicolumn{3}{|c|}{ Database variables } \\
\hline Variable & Description & Codification \\
\hline CEA (Nace) & $\begin{array}{l}\text { Classification of Economic } \\
\text { Activities }\end{array}$ & - \\
\hline LARMAR & Main Market & $\begin{array}{l}\text { 1=Local/Regional } \\
\text { Market; 2=National } \\
\text { Market; 3=European } \\
\text { Market; 4=Other } \\
\text { Countries } \\
\text { (ordinal) }\end{array}$ \\
\hline TURNMAR & $\begin{array}{l}\text { Percentage of total turnover } \\
\text { in } 2012 \text { from product } \\
\text { innovations to market }\end{array}$ & - \\
\hline INPSLG & $\begin{array}{l}\text { New or significantly } \\
\text { improved logistics, delivery } \\
\text { or distribution methods for } \\
\text { inputs, goods or services }\end{array}$ & $0=\mathrm{No} ; 1=$ Yes \\
\hline ROEK & $\begin{array}{l}\text { Acquisition of existing } \\
\text { knowledge from other } \\
\text { enterprises or organisations }\end{array}$ & $0=\mathrm{No} ; 1=$ Yes \\
\hline SCOM & $\begin{array}{l}\text { Sources of information: } \\
\text { Competitors or other } \\
\text { enterprises in your industry }\end{array}$ & $\begin{array}{l}0=\text { Not used; } 1=\text { Low; } \\
2=\text { Medium; } 3=\text { High } \\
\text { importance } \\
\text { (ordinal) }\end{array}$ \\
\hline CMLTAD & Lead time advantages & $\begin{array}{l}0=\text { Not used; } 1=\text { Low; } \\
2=\text { Medium; } 3=\text { High } \\
\text { importance } \\
\text { (ordinal) }\end{array}$ \\
\hline CLUFEED & Client feedback system & $\begin{array}{l}0=\text { Not used; } 1=\text { Low; } \\
2=\text { Medium; } 3=\text { High } \\
\text { importance } \\
\text { (ordinal) }\end{array}$ \\
\hline INCLU & Client based innovation & $0=$ No; $1=$ Yes \\
\hline STALL & $\begin{array}{l}\text { Building alliances with other } \\
\text { enterprises or institutions }\end{array}$ & $\begin{array}{l}0=\text { Not used; } 1=\text { Low; } \\
2=\text { Medium; } 3=\text { High } \\
\text { importance } \\
\text { (ordinal) }\end{array}$ \\
\hline
\end{tabular}

Table 6 shows that the variables in axis2 had an overall contribution of $92.5 \%$, while variables in axis1 had $82 \%$. 
Table 6 Variable contributions (HJ-Biplot output)

\begin{tabular}{l|c|c}
\multicolumn{1}{c|}{ Variable } & Axis1 & \multicolumn{1}{c}{ Axis2 } \\
\hline TURNMAR (turnover from new products) & & 0.760596546 \\
\hline INPSLG (logistics/distribution) & 0.195959596 & \\
\hline $\begin{array}{l}\text { ROEK (knowledge from other firms/ } \\
\text { organisations) }\end{array}$ & 0.213888889 & \\
\hline SCOM (information from the competitors) & & 0.164835165 \\
\hline $\begin{array}{l}\text { CLUFEED (clients' feedback on products/ } \\
\text { services) }\end{array}$ & 0.196969697 & \\
\hline INCLU (innovation from clients' ideas) & 0.214141414 & \\
\hline Sum $=$ & 0.820959596 & 0.925431711 \\
\hline
\end{tabular}

\section{Results and discussion}

In the previous table variables in axis1, such as CLUFEED (feedback from customers on products/services) and INCLU (innovation from customers' ideas), suggest customers' influence. A curious aspect is the lack of results for CMLTAD (time from product idea to market) and STALL (alliances with other enterprises/institutions), which may signal a lack of importance/ influence. The first one is fundamental to enhance business competitiveness (real-time response is one of the most relevant attributes in today's dynamic environment), which can explain the low maturity level of innovation return management in Portuguese firms. On the other hand, the variable TURNMAR (business return from new products) has a high importance in axis2. Being it associated with SCOM (information from the competitors) may evidence that the focus of their innovation strategy resides on competitors' manoeuvres rather than on customers' expectations.

These results reveal that innovation in Portuguese firms is more 'competitor-driven' (as followers) than 'customer-driven' (as pioneers). Nevertheless, a major variable diversity in axis1 may suggest an attempt or, on the contrary, a constraint to consolidate a customerdriven innovation strategy. This question can be further explored in Table 7 and Figure 6 as they illustrate if those variables relate with the axes positively or negatively.

Table 7 Factorial coordinates (HJ-Biplot output)

\begin{tabular}{|c|c|c|}
\hline Variable & $\begin{array}{c}\text { Axis1 } \\
\text { 'Customer-driven' }\end{array}$ & $\begin{array}{c}\text { Axis2 } \\
\text { 'Competitor-driven' }\end{array}$ \\
\hline $\begin{array}{l}\text { TURNMAR (turnover } \\
\text { from new products) }\end{array}$ & 1,006 & $-51,045$ \\
\hline $\begin{array}{l}\text { INPSLG (logistics/ } \\
\text { distribution) }\end{array}$ & $-35,285$ & 7,552 \\
\hline $\begin{array}{l}\text { ROEK (knowledge from } \\
\text { other firms/institutions) }\end{array}$ & $-40,885$ & 7,293 \\
\hline $\begin{array}{l}\text { SCOM (information from } \\
\text { the competitors) }\end{array}$ & 19,704 & 20,514 \\
\hline $\begin{array}{l}\text { CMLTAD (time from } \\
\text { product idea to market) }\end{array}$ & 39,334 & 5,788 \\
\hline $\begin{array}{l}\text { CLUFEED (feedback from } \\
\text { customers on products/ } \\
\text { services) }\end{array}$ & 57,515 & 3,981 \\
\hline $\begin{array}{l}\text { INCLU (innovation from } \\
\text { customers' ideas) }\end{array}$ & $-41,390$ & 5,916 \\
\hline
\end{tabular}

Figure 6. HJ-Biplot factorial space.

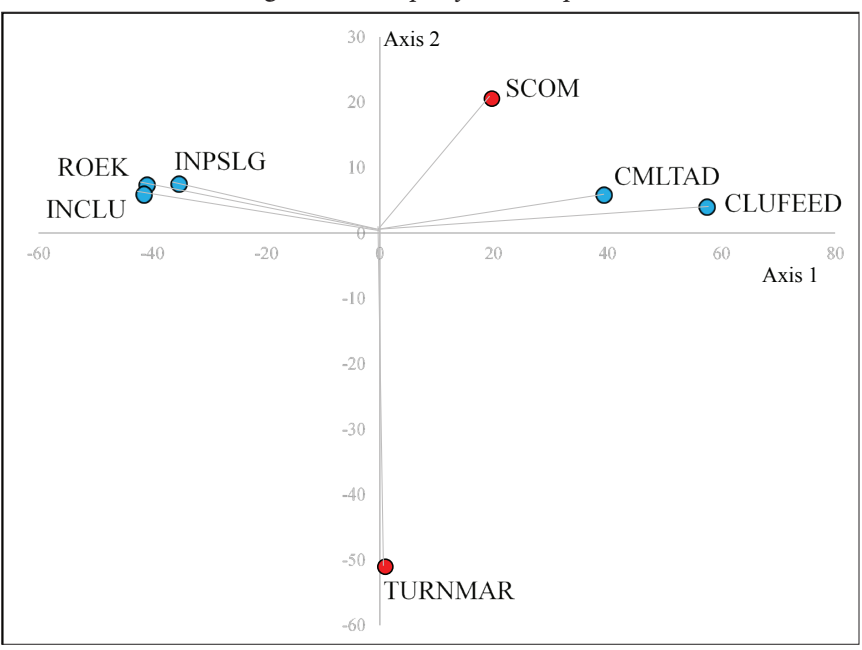

Observing the negative values in axis1, we may acknowledge that when the variable relates to opening the enterprise to the exterior (to customers or other firms/institutions) it appears negatively related. Once more this suggests or corroborates the still low propensity for open innovation and related maturity level of innovation return management in Portuguese firms (acting as followers rather than pioneers).

\section{Conclusion and implications}

Having in mind the theoretical background of these issues, such as the innovation theories on innovation diffusion, open innovation and innovation management, an important reference for Portuguese firms is the ambidextrous innovation paradigm where systematic problem solving and ideation are coupled, i.e., where tactical innovation takes place within strategic innovation on a continual basis. On the other hand, the application of strategic innovation creates the need for tactical innovation to be renewed continually. This method adds the concept of continuous innovation to that of continuous improvement. This can only be achieved by combining exploitative and explorative innovation strategies. Exploitative innovations leverage existing capabilities through activities such as refinement, efficiency, selection, and implementation, while explorative innovations refer to efforts to create future capabilities by means of search, variation, experimentation, and discovery (Schmitt et al., 2010). In order for an organisation to demonstrate this ambidextrous application of innovation, both competencies must be present. Focusing on problem solving and generating profits allow for continuous improvement as well as the continuous addition of features and functions. This helps to maximise the net profitability period for the product/service and provides a stable platform for the generation of the next big achievement (Slocum, 2004). Continued success is based on the repeatable cycle of concept to commercialisation, which will happen when aided by an ambidextrous approach to innovation.

The environment of innovation acceleration programmes has been helping Portuguese firms to cope with the open innovation challenge. Innovation networking/sharing capability facilitates the development 
of knowledge-intensive products/services and allows firms to identify and exploit performance opportunities in international markets. Entrepreneurial cooperation of ideas and activities is really motivating and differentiating. The resulting partnerships or teams shorten and accelerate firms' learning processes. These dynamic entrepreneurial engines deal with firms' needs and access to network resources in the various stages of their development. Sá and Lee (2012) stated that accelerators' central features are the provision of innovation consulting and networking opportunities for entrepreneurs to establish collaborative relationships with other creative agents. A recent study has emphasised the crucial role of multifaceted relations between accelerated firms and how they can develop through different processes (Pellinen, 2014).

Most firms exchange knowledge and experiences related to the various phases and processes in developing a business. Even though they have different products and technologies and target a different market from other firms, they evolve through the same stages of emergence and growth. The challenges they face and the experiences they gain are similar and transferable, besides the generic resources that they are able to share. Oakey (2007) noted that some entrepreneurs are reluctant to discuss their new product ideas with other entrepreneurs for fear that their intellectual property will be copied. Indeed, a large exhibition is accompanied by increased risk of unwanted disclosure of the idea to potential competitors. But the more the idea is exposed, the greater the chance is of a potential investor/partner to recognise its business potential. Also, these programmes can include register or patent consulting (to protect the idea). The open innovation contracts have to actively safeguard these issues, where both parties are linked to a legal agreement that must be met or face penalties for damages.

Seed accelerators' ecosystem in Portugal is still in its first steps, even though the 'Lisbon Challenge' event is a great example of its growth. Also, there is an upcoming important governmental strategic support programme called 'Start-up Portugal'. Portuguese start-ups represent $6.5 \%$ of businesses and, on average, $74 \%$ of them effectively start their activity. However, after three years less than $50 \%$ exhibit activity and by the fifth year the survival rate is $40 \%$. Lessons from the innovation management matrix show us that successful innovative firms have been cutting back on activities that were not leading to the outcomes needed. And with the right partners they had more ideas invested, executed and diffused. In this way, they get to learn about how to use their resources more effectively. This kind of management for innovation sustainability must reside in a balance between innovation commitment and competence.

Another challenge that Portugal has to cope with in the near future is related to smart cities and smart city accelerators.

\section{The challenge of 'smart city' accelerators}

While Portugal is at the level of receiving the 'web summit' acceleration event, the US is already at the level of 'smart cities summit'. In the latter, held in Boston, speakers stressed that building a smart city involves many vendors whose products and services align and work together (Shea, 2016). Many appeals were made to the binding power of standards. For example, with the help of City Digital, a smart city accelerator that brings together universities, corporations and city partners, the city of Chicago gathered a group (including Microsoft, Senformatics, West Monroe Partners, Opti and AECOM) to co-design an IoT project to benefit both the city and its partners. Resulting platforms have to be inclusive not just from a city's perspective, but from a vendor's perspective, in order to bring in all the great innovation and technologies that vendors have and create a blueprint. There is not a single solution or vendor for everything, thus there must be a consortium of partners that provide the right solution and are able to work together in a cohesive way. Competitors are actually collaborators, because they want to be able to make this happen. This framework is also important to delineate the best activity options for innovation accelerators of firms.

To get the maximum value from IoT, managers must begin to transform their organisations based on key cases that derive greater value from IoT. These cases include smart grid, smart buildings, healthcare and patient monitoring, industry, education, tourism, advertising, entertainment, among others. The value put into play by IoT is increasingly based on the widespread adoption of IoT by private sector companies over the next decade. Then, robust security capabilities (both logical and physical) and privacy policies are critical features of IoT's economy. This growth could be inhibited if the security capabilities of the technology are not combined with policies and processes designed to protect the privacy of both companies and individuals. After the vendors have worked together and cities have found their ideal mix of technologies, it is important to remember those that will be implementing them and using the data. The benefits of smart cities and the data they produce may make sense to some specialists, but not to the average citizen (RES, 2011). It is important to have conversations with the public to ensure they understand what the projects are for and how building a smart city can help them.

\section{References}

Acquisti, A., Chaminade, C. and Roberts, H. (2002), "Social capital as a mechanism: Connecting knowledge within and across firms", proceedings of the 3rd European Conference on Organizational Knowledge, Learning and Capabilities, Athens, Greece.

Chesbrough, H. (2003a), “The era of open innovation”, MIT Sloan Management Review, Vol. 44 No. 3, pp. 35-41. doi: 10.12691/jfe-2-5-9.

Chesbrough, H. (2003b), Open Innovation: The New Imperative for Creating and Profiting from Technology, Harvard School Press, Boston, USA.

Chesbrough, H., Vanhaverbeke, W. and West, J. (2006), Open Innovation: Researching a New Paradigm, Oxford University Press, London, UK.

Christiansen, J. (2009), "Copying y combinator: A framework for developing seed accelerator programmes", University of Cambridge, Boston, USA. 
Cohen, W. and Levinthal, D. (1990), "Absorptive capacity: A new perspective on learning and innovation", Administrative Science Quarterly, Vol. 35, pp. 128-152. doi: 10.2307/2393553.

Dalakian, G. (2013), “90\% of tech startups fail”, available at: http:// www.wamda.com/2013/02/90-percent-of-tech-startups-fail-infographic (accessed 12 January 2017).

DGEEC (2014), "CIS 2012 - community innovation survey", available at: http://www.dgeec.mec.pt/np4/207/ (accessed 11 October 2016).

Du Preez, N., Louw, L. and Essmann, H. (2006), "An innovation process model for improving innovation capability", Journal of High Technology Management Research, pp. 1-24.

Faria, R. (2013), "Startups representam 6,5\% do tecido empresarial em Portugal”, available at:http:/www.jornaldenegocios.pt/empresas/ detalhe/startups_representam_65_do_tecido_empresarial_em_portugal.html (accessed 2 January 2017).

Galindo, M. (1986), “Una alternativa de representación simultánea: HJ-BIPLOT”, Qüestiió, Vol. 10, pp. 13-23.

Hassanalieragh, M., Page, A., Soyata, T., Sharma, G., Aktas, M., Mateos, G., Kantarci, B. and Andreescu, S. (2015), "Health monitoring and management using internet-of-things (IoT) sensing with cloudbased processing: Opportunities and challenges", proceedings of the 12th IEEE international conference on services computing, New York, USA.

IPACSO (2014), "The evolution of innovation framework models", available at: http://ipacso.eu/innovation-modelling/innovation-model-analysis/187-the-evolution-of-innovation-framework-models. html (accessed 12 January 2017).

Jansen, J., Simsek, Z. and Cao, Q. (2012), “Ambidexterity and performance in multiunit contexts: Cross-level moderating effects of structural and resource attributes", Strategic Management Journal, Vol. 3 No. 11, pp. 1286-1303.

Kastelle, T. (2012), "Procter \& Gamble - using open innovation to become a world class innovator", available at: http://timkastelle.org/ blog/2012/05/procter-gamble-using-open-innovation-to-become-aworld-class-innovator/ (accessed 2 February 2017).

Laursen, K. and Salter, A. (2006), "Open for innovation: The role of openness in explaining innovation performance among UK manufacturing firms", Strategic Management Journal, Vol. 27 No. 2, pp. 131-150. doi: 10.1002/smj.507.

Leonard-Barton, D. (1995), Wellsprings of Knowledge: Building and Sustaining the Sources of Innovation, Harvard Business Press, Boston, USA.

Miller, P. and Bound, K. (2011), “The startup factories”, available at: http://www.nesta.org.uk/publications/startup-factories (accessed 2 February 2017).
Niewolny, D. (2013), "How the internet of things is revolutionizing healthcare", available at: https://cache.freescale.com/files/corporate/doc/ white_paper/IOTREVHEALCARWP.pdf (accessed 15 January 2017).

Oakey, R. (2007), "Clustering and the R\&D management of hightechnology small firms: In theory and practice", R\&D Management, Vol. 37 No. 3, pp. 237-248. doi: 10.1111/j.1467-9310.2007.00472.x.

Pellinen, K. (2014), "The interplay of entrepreneurial and network activities in the entrepreneurial process: A relational analysis", International Journal of Entrepreneurship and Innovation, Vol. 15 No. 1, pp. 17-28. doi: 10.5367/ijei.2014.0137.

Powell, W., Koput, K. and Smith-Doerr, L. (1996), "Interorganizational collaboration and the locus of innovation: Networks of learning in biotechnology", Administrative Science Quarterly, Vol. 41 No.1, pp. 116-145. doi: 10.2307/2393988.

Sá, C. and Lee, H. (2012), "Science, business, and innovation: Understanding networks in technology-based incubators", R\&D Management, Vol. 42 No. 3, pp. 243-253.

Sarkar, S. (2014), Entrepreneurship and Innovation, Escolar Editora, Lisboa, Portugal.

Schmitt, A., Probst. G. and Tushman, M. (2010), "Management in times of economic crisis: Insights into organizational ambidexterity", Management, Vol. 13 No. 3, pp. 128-150. doi: 10.3917/mana.133.0128.

Schreuders, J. and Legesse, A. (2012), “Organizational ambidexterity: How small technology firms balance innovation and support”, Technology Innovation Management Review, Vol. 2 No. 2, pp. 17-21. doi: 10.22215/timreview/522.

Shan, W., Walker, G. and Koput, B. (1994), "Interfirm cooperation and startup innovation in the biotechnology industry", Strategic Management Journal, Vol. 15 No. 5, pp. 387-394.

Shea, S. (2016), "Building a smart city: It takes a village", available at: http://internetofthingsagenda.techtarget.com/news/450404467/Building-a-smart-city-It-takes-a-village?utm_medium=EM\&asrc=EM NLS_69587037\&utm_campaign $=20161213$ _Feel\%20the $\% 20$ love, \%20 smart \%20 cities \&utm_source =NLS\&track $=\mathrm{NL}$ $1843 \& a d=911641 \& s r c=911641$ (accessed 14 February 2017).

Slocum, M. (2004), “Ambidextrous innovation”, available at: https:// triz-journal.com/innovation-theories-strategies/innovation-general/ ambidextrous-innovation/ (accessed 15 January 2017).

Tyagi, S., Agarwal, A. and Maheshwari, P. (2016), "A conceptual framework for IoT-based healthcare system using cloud computing", proceedings of the 6th international conference on cloud system and big data engineering, Noida, India.

Veugelers, R. (1997), "Internal R\&D expenditures and external technology sourcing", Research Policy, Vol. 26 No. 3, pp. 303-315. doi: 10.1016/S0048-7333(97)00019-X. 
